\title{
Pendidikan Agama Berbasis Kerukunan
}

\author{
Roibin
}

Penulis adalah Dosen Fakultas Syariah Universitas Islam Negeri (UIN) Malang

\section{ABSTRACT}

The Islamic education has ever been sociologically and historically regarded as Islamic religious education. It is intended to differentiate it from general (secular) education. This view is considered as the reason for the presence of Islamic religious school (madrasah diniyah) and the dichotomy between religious education and general (secular) education. Since then, the treatment for students'.characters, moral, attitude, personality or what's commonly known as affective aspects is reliedon religious education. On the contrary, the treatment for students' psychometrics and cognitive aspects is charged to general education system.

\section{A. Pendidikan Agama: antara harapan dan tantangan}

Hampir semua tujuan pendidikan, baik dalam kaca mata umum atau agama selalu mengidealkan terciptanya sikap anak didik yang dewasa. Dewasa intelektualnya emosionalnya, lebih-lebih spiritualnya. Proses pendidikan yang hanya menekankan kedewasaan intelektual dan mengabaikan kedewasaan emosional serta spiritual akan memunculkan manusia yang cerdas tapi tidak bermoral, intoleran, miskin solidaritas dan tidak humanis. Selama ini, Pendidikan agama secara normatif diakui mampu memformulasi dan mengakumulasi idealitas tujuan pendidikan tersebut. Namun secara empiris, lembaga pendidikan agama maupun lembaga

Ulul Albab, Vol. 4 No. 1, 2003 
lain yang terkait dengan simbol agama dalam praktiknya sering mengecewakan dan tidak konsisten terhadap misi idealnya.

Dari sini akhirnya muncul pertanyaan apa yang membedakan secara riil pendidikan agama di Indonesia dan pendidikan Barat (sekuler)? Di Barat tidak mengenal adanya pendidikan agama, namun sikap kejujuran, kedisiplinan, kebersihan, keadilan dan kedemokratisasian relatip telah membudaya dan mentradisi di kalangan peserta didik mereka. Sebaliknya, Indonesia dengan pendidikan agamanya tidak bisa menghasilkan orang yang seperti itu. Padahal jika dikaji lebih mendetail, kejujuran, kedisiplinan, kebersihan, solidaritas sosial, toleran, keadilan dll, 一yang telah menjadi mental mereka - merupakan esensi dasar dari ajaran masing-masing agama. Mengapa hal ini bisa terjadi ? Adakah faktor yang mempengaruhi gagalnya sebuah pendidikan Agama?

Tulisan ini akan melihat berbagai latar belakang gagalnya pendidikan agama serta faktor-faktor yang berpengaruh di dalamnya. Tulisan ini akan diawali dengan konsep pendidikan secara teoretis oleh para pakar pendidikan, selanjutnya mencermati dan mengkritisi model pendidikan secara umum, utamanya adalah pendidikan agama yang selama ini dinilai kurang memberikan andil bagi penciptaan kerukunan, baik kerukunan antar sesama umat manusia maupun antar agamaagama.

Secara teoretis istilah pendidikan di mata bangsa Indonesia, memiliki makna yang luas dan universal. Karena keuniversalannya, maka kata-kata pendidikan, pengajaran, bimbingan dan atau pelatihan di anggap sebagai istilah teknis yang tidak lagi dibeda-bedakan oleh masyarakat kita. Berati pula dianggap telah melebur dalam satu makna baru, yaitu pendidikan. 'Dalam maknanya seperti ini pendidikan dituntut mampu memberikan harapan dari peserta didiknya hidup mandiri. ${ }^{2}$

Sementara itu dalam Islam dikenal istilah-istilah tarbiyah, ta'lim, ta'dib, tahdzib, tadrib, dan irsyad, Masing-masing term tersebut dalam tataran operasionalnya memiliki makna yang berbeda-beda. Ada yang mengatakan bahwa istilah tarbiyahmisalnya, adalah istilah yang paling tepat untuk menyebut pendidikan Islam, demikian pandangan Abdurrahman al-Nahlawy. ${ }^{3}$ Berbeda dengan Jalal, ${ }^{4}$ istilah $t a^{\prime}$ 'lim menurutnya lebih memilikipesan yang luas dan umum jika dibandingkan dengan istilah tarbiyah. Sementara itu pula term ta'dib dalam pandangan Syekh Naquib al-Atas adalah term yang lebih tepat untuk mewakili sebutan pendidikan Islam. ${ }^{5}$ 
Lebih menarik lagi, ketika term-term di atas dikaitkan dengan istilah-istilah dalam Islam, misalnya al-tarbiyah al-Diniyah (keagamaan), al-tarbiyah alIslamyah (keislaman), atau al-ta'lim al-Diny dan al-ta"lim al-Islamy, ternyata term-term tersebut juga akan menimbulkan perspektif baru yang berbeda-beda pula. Hal demikian utamanya jika dibidik dari perspektif historis-sosiologis perkembangan pendidikan Agama Islam.

Secara historis-sosiologis pendidikan Agama Islam pernah dimaknai sebagai pendidikan/pengajaran keagamaan/keislaman. Hal ini dimaksudkan untuk membedakan dengan pendidikan umum (sekuler). ${ }^{6}$ Pandangan inilah yang dianggap sebagai penyebab awal lahirnya madrasah diniyah, hingga melahirkan dikotomi antara pendidikan agama dan pendidikan umum (sekuler). Sejak itulah tanggungjawab pembinaan watak, moral, sikap, kepribadian atau yang lebih akrab disebut dengan aspek afektif diserahkan sepenuhnya pada pendidikan agama. Sementara itu pendidikan umum hanya sebatas pada aspek psikomotor dan kognitif.

Tanggung jawab dari masing-masing aspek, sebagaimana tersebut di atas, sampai saat ini masih tetap berjalan. Dengan kata lain aspek afektif, secara tidak langsung menjadi tanggung jawab pendidikan agama an sich. Persoalannya adalah bagaimanakah peranan pendidikan agama baik yang diajarkan dilembaga formal atau non formal. Sudah efektifkah pendidikan agama yang selama ini diberikan kepada mereka? Jika belum mengapa itu terjadi ? Apakah kegagalan tersebut karena kesalahan metodologis dalam memahami muatan-muatan universal materi keagamaan?

\section{B. Bagaimana Idealnya Pendidikan Agama?}

Secara normatif-doktriner, Basmar mengatakan bahwa salah satu upaya penanggulan kenakalan remaja yang cukup efektif adalah dengan jalan menanamkan pendidikan agama dalam jiwa anak didik kita. ${ }^{7} \mathrm{Hal}$ demikian dikarenakan pendidikan agama menurut Zakiah Darajat, bukanlah sekedar memberikan pelajaran agama secara teratur dan sengaja oleh guru di sekolah. Lebih jauh dari itu menurutnya adalah penanaman jiwa agama yang dimulai dari pendidikan keluarga sejak kecil, dengan jalan membiasakan anak untuk berbuat baik. ${ }^{8}$

Ulul Albab, Vol. 4 No. 1, 2003 
Lebih luas lagi moh. Dimyati mengatakan bahwa pendidikan agama adalah sangat luas, kompleks dan multidimensional. Dalam pandangannya pendidikan agama adalah pendidikan yang bertugas 1). menggarap bakat non rasional, yaitu pada aspek rasa dan keimanan, 2). melakukan universalisme manusia secara utuh, eksistensial emansipatoris, 3). menggarap dimensi individual, sosial, moral dan kepribadian, mengingat budaya agama yang imperatif, 4). menggarap individu yang terkait dengan tradisi di mana ia melangsungkan hidupnya, 5). kegiatan yang bersifat universal yang berangkat secara individual dan menimbulkan seseorang yang unik, 6). membangkitkan seseorang yang beriman dan bertaqwa, beramal saleh dan mengagamakan pribadi secara lintas sosial, budaya, agama dan lintas psikologi universal.9

Dari pandangan tersebut, pendidikan agama setidaknya harus mencerminkan sifat toleran, solidaritas, inklusif, humanis, egaliter, pluralis dan tidak normatif doktriner, intoleran, lebih-lebih eksklusif.

Atas dasar inilah hepotesa sementara penulis mengatakan bahwa kegagalan sosialisasi nilai-nilai universal ajaran agama, disebabkan karena pemahaman agama selama ini masih terbatas pada tataran kesalehan ritual formalistik an sicls. Masih menekankan pada hal-hal luar, misalnya, upacara, peraturan, ritus, hukum dan lambang-lambang, meskipun hal tersebut juga merupakan bagian yang tak terpisahkan dari nilai universal agama. Sementara spirit atau ruh dari hukum tersebut, yaitu iman, harapan, kasih sayang yang berpotensi melahirkan ajaran-ajaran kerukunan belum banyak disentuh. Dengan kata lain pendidikan agama selama ini terjebak pada upaya membuat orang beragama, dan tidak mendorong untuk beriman.

Hasil observasi yang diadakan oleh PPIM (Pusat Penelitian Islam dan Masyarakat) IAIN Syarif Hidayatullah Jakarta yang baru-baru ini juga dimuat di Majalah Tempo, telah mengungkap hal yang sama. Bahwa perilaku keberagamaan dari sejumlah kota-kota besar yang ada di Indonesia mayoritas masih menekankan pada dimensi kesalehan individual tersebut. Bersamaan dengan itu pula, fenomena KKN, intoleran, miskin solidaritas, kerusuhan, kekerasan, eksploitasi, hegemoni juga marak di sejumlah kota-kota besar tersebut. Padahal fenomena semacam ini akan mudah dilerai melalui pendekatan Pendidikan Agama yang perhatian pada wawasan kerukunan.

Bagaimanakah seharusnya arah dasar Pendidikan Agama? Untuk membawa kesadaran orang semakin beriman ataukah sekedar mengajak mereka beragama. 
Membawa orang untuk to be religion atau menuju to have a religion. Sementara itu religiusitas adalah sikap dasar yang membuat orang beramal baik, bersikap penuh belas kasih, merasa rindu dan ingin dekat dengan Tuhan, penuh cinta dan sayang, lembut hati dan mudah memaafkan sekaligus memiliki bela rasa. Inilah persoalan-persoalan yang sangat inti dalam beragama, yang seharusnya menjadi potret pendidikan Agama.

Samuel P. Huntington dalam bukunya "the Clash of Civilization and the Remarking of Word Order" mengatakan bahwa benturan yang terjadi antar peradaban sangatlah besar pengaruhnya terhadap perdamaian dunia (kerukunan). Dalam konteks dunia internasional peradaban merupakan pengaman terpenting dalam mencegah terjadinya perang dunia. ${ }^{10}$ Padahal yang disebut sejarah peradaban ialah sejarah manusia itu sendiri. Sementara agama adalah karakteristik utama yang mencirikan sebuah peradaban. Lebihdari itu Christopler Dowson, "mengatakan bahwa agama-agama besar adalah bangunan dasar bagi peradaban-peradaban besar.

Tidaklah salah jika dikatakan bahwa sejarah peradaban adalah sejarah manusia, karena pada realitanya manusia adalah makhluk yang berbudaya, beretika, belajar. Oleh karenanya ia membutuhkan pendidikan dan pengajaran untuk mendewasakan dan memajukan dirinya. Sementara dalam kaitanya dengan upaya memajukan dirinya harus menghadapi banyak aspek. Sedangkan di antara aspek kemanusiaan yang sejati adalah yang mendasar. Sementara untuk mencapainya harus melalui pendidikan agama (al-tarbiyah al-Diniyah). ${ }^{12}$

Menurut Ibrahim Bafadhal pendidikan agama memiliki 2 visi dan misi secara bersamaan. Pertama : pendidikan agama yang diarahkan pada peningkatan keimanan, pemahaman, penghayatan dan pengamalan siswa terhadap agama tersebut. Kedua: Pendidikan agama diarahkan pada upaya pembentukan kesadaran siswa untuk menjadi seorang muslim yang mampu menghormati agama lain dalam hubungan kerukunan antar umat beragama dalam masyarakat. ${ }^{13}$ Masih menurutnya orientasi pendidikan agama tidak cukup hanya menyangkut hal-hal luar, sebagaimana yang telah diungkap di atas, yaitu seperti upacara, peraturan, ritus, hukum, lambanglambang dan sederet kesalehan ritual formalistik lainnya. Pendidikan agama tidak bisa disamakan dengan segi-segi formal itu. Meski ia juga merupakan bagian penting dalam agama.

Ulul Albab, Vol. 4 No. 1, 2003 
Dengan kata lain agama yang dipentingkan bukan huruf-huruf yang tersusun menjadi hukum, namun yang lebih penting dari itu semua adalah ruh/ semangat dari agama itu sendiri, yaitu iman, harapan dan kasih sayang. Karena dengan pendidikan model yang terakhir ini, manusia akan memiliki kepribadian ideal, antara lain jiwa solidaritas yang tinggi, jujur, adil, damai, rukun dan jauh dari perpecahan, permusuhan, kekerasan, konflik horisontal dan ketegangan antar umat beragama.

\section{Pendidikan Agama dan Solidaritas Sosial}

Sebagaimana dikemukakan di atas bahwa tanggung jawab pendidikan agama secara historis-sosiologis telah terpetakan secara jelas, yaitu membentuk sikap, moral dan kepribadian manusia yang berperadaban tinggi. Namun demikian dalam tataran praktis, harapan ini sering terhambat oleh tuntutan idealis dari masingmasing agama. Agama yang mestinya menumbuhkan jiwa dan sikap toleran. Mengakui kebenaran ajarannya dan menghormati kebenaran ajaran agama di luar dirinya. Namun karena agama yang tampil dengan idealisme yang panatis maka keragaman agama menjadi persoalan tersendiri.

Disini pluralisme agama setidaknya harus menjadi kekuatan konstruktiftransformatif, dan bukan kekuatan destruktif. Potensi pertama, yaitu kekuatan konstruktif-transformatif akan berkembang jika masing-masing komunitas agama memahami dan menjunjung tinggi nilai toleransi dan kerukunan. Sebaliknya potensi destruktif akan dominan jika masing-masing komunitas agama tidak memiliki sikap toleran, bahkan menganggap agamanya paling benar, superior dan memandang inferior bagi agama lain. ${ }^{14}$

Oleh karenya pendidikan agama idealnya mampu membentuk watak manusia, bahwa agama merupakan kebutuhan ruhani bagi penciptaan kerukunan dan kedamaian. Ia pun juga berfungsi sebagai pemupuk persaudaraan dan ketentraman sesuai dengan misinya.

Dari dialog ini, kita dihadapkan pada pertimbangan-pertimbangan dilematis, pertama : Benarkah agama selama ini berperan sebagai pelerai konflik dan pemersatu sosial? Benarkah agama secara empirik juga berperan sebagai pemicu konflik ? Untuk menangkap jawaban secara tepat dari pertanyaan tersebut, tergantung pada formulasi pendidikan agama. Sudahkan pendidikan agama yang 
kita formulasi sarat dengan wawasan kerukunan ? Atau masih tampak sebaliknya. Padahal secara normatif, pendidikan agama selalu menekankan pendidikan yang berwawasan kerukunan, kejujuran, keadilan dan cinta kasih. Dengan demikian jika pendidikan agama justru memiliki potensi untuk menimbulkan konflik, maka yang disalahkan bukan agamanya, melainkan pelaku agama itu sendiri. Atas dasar inilah sèmestinya kita harus bisa mengembalikan ajaran universal dari agama tersebut, dengan jalan menseimbangkan kesalehan ritual formalistik dan kesalehan sosial substansialistik.

Dengan demikian berarti kita telah mampu memotret perilaku keberagamaan Muhammad. Selanjutnya bagaimana hasil potret keberagamaan tersebut bèrimplikasi dalam perilaku keseharian kita ? Inilah tugas praktis kita.[] 